\title{
\begin{tabular}{l|l|l} 
& Jurnal Kependidikan Dasar & Volume : 3 \\
Nomor : 2 \\
Islam Berbasis Sains & Tahun : 2018 \\
\hline
\end{tabular}
}

\section{Penalaran Adaptif Siswa MI Kelas Rendah Pada Materi Operasi Hitung}

\author{
Bilangan Bulat \\ Sofwan Hadi \\ PGMI IAIN Ponorogo \\ Surel : sofwan@iainponorogo.ac.id
}

\begin{abstract}
Abstrak
Penalaran merupakan suatu proses siswa untuk memahami pengetahuan yang dipahami. Konsep penalaran sangat penting diketahui oleh guru terutama untuk siswa kelas rendah. Pada penelitian ini kelas rendah adalah kelas 3 MI. Penalaran adaptif perlu dikaji untuk mengetahui kemapuan siswa ketika menalar pemahaman tentang matematika dan proses siswa mengadaptasi pemahaman baru dengan cara pemikiran yang mereka punyai. Penelitian ini termasuk penelitian kualitatif dengan jenis penelitian Studi Kasus. Sampel pada penelitian ini akan di golongkan berdasarkan kemampuan kognitif, yang terdiri dari kognitif tinggi, sedang dan rendah. Sedangkan subjek dalam penelitian ini sebanyak 20 siswa. Penelitian ini menghasilkan ada 4 faktor aktifitas penalaran adaptif siswa.
\end{abstract}

Kata Kunci : Penalaran Matematika; Penalaran Adaptif;

\begin{abstract}
Abstact
The reasoning is a process of students to understand the knowledge that is appreciated. The concept of thinking is fundamental to be known by teachers, especially for low-grade students. In this study, the low class is class 3 Madrasah Ibtiaiyah. Adaptive reasoning needs to be studied to determine the ability of students when reasoning understanding of mathematics and the process of students adapting new knowledge with the way of thinking they have. This research is qualitative research with case study research type. The sample in this study will be classified based on cognitive abilities, which consist of high, medium, and low cognitive. While the subjects in this study were 20 students. This research resulted in 4 factors of students' adaptive reasoning activities
\end{abstract}

Keyword : Mathematic Logic; Adaptive Logic 


\section{A. Latar Belakang}

Kesuksesan dalam melakukan pembelajaran bisa diakibatkan oleh beberapa faktor. Salah satunya adalah peran Guru dalam mengontrol kegiatan pembelajaran. Guru profesional mampu menyelami kelas dengan berbagai pendekatan. Kesulitan dalam mengontrol kelas salah satunya dikarenakan kelas yang ada siswanya heterogen. Siswa yang mempunyai karakter siswa yang berbeda mempunyai tingkat kesulitan yang berbeda, sehingga peran guru dalam pembelajaran harus bisa mengidentifikasi kesulitan belajar siswa yang tentunya tidak sama antarsiswa yang satu dengan yang lain. Menurut Wood $^{1}$ ada beberapa karakteristik kesulitan siswa dalam belajar matematika: (1) kesulitan membedakan angka, simbol-simbol, serta bangun ruang, (2) tidak mampu mengingat dalil matematika, (3) kesulitan menulis angka, (4) tidak memahami simbol-simbol matematika, (5) lemahnya kemampuan berpikir abstrak, (6) lemahnya kemampuan metakognisi (lemahnya kemampuan mengidentifikasi serta memanfaatkan algoritma dalam memecahkan soal-soal matematika).

Kesulitan yang terjadi pada individu terjadi ketika individu dalam kelas tidak mampu mengonstruksi pemahaman yang dia dapatkan. Konstruksi pemahaman menurut Ormrod $^{2}$ adalah proses mental ketika seseorang mampu merangkai informasi yang diperolehnya, sehingga menghasilkan suatu pemahaman materi yang dikuasai oleh

\footnotetext{
${ }^{1}$ Derek Wood, Kiat Mengatasi Gangguan Belajar (Jakarta: Kata Hati, 2007).

2 Jeanne Ellis Ormrod, PsikologiPpendidikan, 2 ed. (Jakarta: Erlangga, 2008).

${ }^{3}$ Lev Semenovich Vygotsky, Mind in society: The development of higher psychological processes (Harvard university press, 1980).
}

individu. Proses konstruksi pemahaman siswa ini perlu diamati oleh guru untuk mengetahui tingkat pemahaaman siswa. Menurut Vygotsky $^{3}$, pengetahuan siswa didapatkan oleh seseorang tidak dipeoleh dari transfer pikiran orang lain, tetapi dari kemampuan orang tersebut memahami informasi yang diterima orang tersebut untuk menjadi pengetahuan yang dia pahami. ${ }^{4}$ Dengan demikian, ketika siswa memahami materi, perlu diamati proses konstruksi yang sudah dilakukan oleh siswa. Hal itu bisa digunakan sebagai bahan scaffolding guru. Menurut Sofwan ${ }^{5}$, scaffloding guru harus secukupnya agar siswa bisa mandiri dalam mengkonstruksi pemhamannya dan tidak merasa kesulitan dalam memahami materi.

Pemahaman siswa bisa dilihat dari cara siswa mengomunikasikan pemahaman yang diperoleh, sehingga proses identifikasi konstruksi pemahaman terlihat ketika siswa mampu menyampaikan gagasan secara dengan lisan maupun tulisan secara baik. Proses komunikasi pemahaman yang diperoleh siswa merupakan salah satu identifikasi hasil pembelajaran sesuai dengan target. Karena output pembelajaran adalah siswa bisa menyampaikan gagasan pribadi tentang konsep yang dipahaminya. Pemahaman siswa bisa direpesentasi dengan menggunakan 4 aspek, yaitu representasi visual, representasi gambar, representasi

\footnotetext{
${ }^{4}$ Akbar Sutawidjaja dan Jarnawi Afgani Dahlan, Pembelajaran matematika (Jakarta: Universitas Terbuka, 2014).

${ }^{5}$ Sofwan Hadi, "Scaffolding dalam Menyelesaikan Permasalahan KPK dan FPB," Ibriez: Jurnal Kependidikan Dasar Islam Berbasis Sains 1, no. 1 (2016): 141-148.
} 
persamaan atau ekspesi matematis, dan representasi kata atau teks tertulis. ${ }^{6}$

Peran penalaran matematika untuk meningkatkan kemampuan pemecahan masalah matematika siswa oleh Ani Minarni ${ }^{7}$. Penelitian ini menguraikan penelitian yang berkaitan dengan penalaran matematika. Penelitian ini menghasilkan tentang sulitnya berpikir abstrak pada siswa usia sekolah dasar. Kajian pola bernalar yang adaptif merupakan salah satu kajian yang perlu diteliti. Penalaran adaptif bisa dijadikan sarana untuk membantu siswa sekolah dasar dalam mengabstraksi pengetahuan yang baru.

$$
\text { Scaffolding dalam Menyelesaikan }
$$
Permasalahan KPK dan FPB oleh Sofwan Hadi dari IAIN Ponorogo ${ }^{8}$. Penelitian ini menguraikan pentingnya bantuan (scaffolding) guru, agar proses konstruk pengetahuan siswa bisa terserap dengan baik. Saran penelitian ini perlu dikaji lagi tentang faktor yang bisa dijadikan bantuan, agar bantuan yang diberikan oleh guru tidak terlalu berlebih dan bisa secukupnya. Kajian penalaran adaptif bisa dijadikan informasi untuk menyiapkan bantuan yang cukup bagi siswa pada jenjang Sekolah Dasar.

Kemampuan Komunikasi Matematis Dalam Pembelajaran Statistika Elementer Melalui Problem Based-Learning (PBL) oleh Fatia Fatimah dari Universitas Terbuka Padang ${ }^{9}$. Penelitian ini menggunakan

\footnotetext{
${ }^{6}$ Karunia Eka Lestari dan Mokhammad Ridwan Yudhanegara, Penelitian Pendidikan Matematika (Bandung: Refika Aditama, n.d.).

${ }^{7}$ Minarni Ani, "Peran Penalaran Matematik Untuk Meningkatkan Kemampuan pemecahan Masalah Matematik Siswa.," in Prosiding Seminar Nasional Matematika dan Pendidikan Matematika (2010): " Peningkatan Kontribusi Penelitian dan Pembelajaran Matematika dalam Upaya Pembentukan Karakter Bangsa" (Jurusan Pendidikan Matematika FMIPA UNY, 2010).
}

pendekatan kuantitif eksperimen dengan cara membandingkan kelas yang menggunakan PBL dan tidak mennggunakan PBL. Hasil penelitian ini menyatakan penelitian yang menggunakan PBL tidak meningkatkan komunikasi matematis tetapi meningkatkan kemampuan memecahkan masalah matematis. Penelitian ini perlu dianalisa proses komunikasi matematis siswa, agar penggunaan media yang menggunakan pendekatan PBL bisa meningkatkan kemampuan komunikasi matematis dan kemampuan memecahkan masalah matematis, sehingga target siswa bisa memahami materi dengan baik bisa ditunjang dengan kemampuan mengungkapkan hasil penelitian dengan lisan atau tulisan.

Kecakapan matematis ini, menurut Kilpatrick $^{10}$ terdiri dari (1) pemahaman konseptual (conceptual understanding); (2) kelancaran prosedural (procedural fluency); (3) kompetensi strategis (strategic competence); (4) penalaran adaptif (adaptive reasoning); dan (5) disposisi produktif (productive disposition). Kemampuan penalaran Adaptif merupakan kemampuan yang perlu untuk dikaji pada anak usia Madrasah Ibtidaiyah terutama di kelas rendah (kelas 1, kelas 2 dan kelas 3). Karena pada masa ini siswa belum mampu mengabstraksi pengetahuan yang dipahami sehingga perlu penalaran yang diadaptif dari hal-hal yang

\footnotetext{
${ }^{8}$ Hadi, "Scaffolding dalam Menyelesaikan Permasalahan KPK dan FPB."

${ }^{9}$ Fatia Fatimah, "Kemampuan Komunikasi Matematis dalam Pembelajaran Statistika Elementer melalui Problem Based-Learning," Jurnal Cakrawala Pendidikan 5, no. 2 (2013), http://journal.uny.ac.id/index.php/cp/article/view/156 2.

${ }^{10}$ National Research Council dan Mathematics Learning Study Committee, Adding it up: Helping children learn mathematics (National Academies Press, 2001).
} 
ada disekitar. Penalaran adaptif ini sebagai bahan informasi agar guru bisa menyiapkan pembelajaran dengan baik. Menurut Henningsen ${ }^{11}$ ada beberapa hal yang perlu dipersiakan guru untuk pembelajaran matematika, yaitu perlunya memperhatikan pembelajaran agar sesuai dengan kemampuan berpikir dan penalaran siswa. Informasi tentang proses penalaran adaptif ini sengat penting agar desain pembelajaran yang dihasilkan sesuai dengan kemampuan siswa. Oleh karena peneliti mengambil judul Penalaran Adaptif Siswa MI Kelas Rendah Pada Materi Operasi Hitung Bilangan Bulat.

\section{B. Metode Penelitian}

Penelitian ini menggunakan tes dan wawancara utuk menggalian data. Sebelum melakukan pengambilan data. Peneliti akan melihat karakter dari subjek penelitian. Langkah yang dilakukan dengan bertanya kepada kepala sekolah dan guru pamong tentang kondisi siswa dan kelas yang dijadikan subjek penelitian. Kegiatan ini dilakukan agar peneliti bisa mengetahui karakteristik dari subjek penelitian dengan maksimal. Hasil konsultasi juga digunakan sebagai masukkan untuk pengembangan instrumen penelitian yang berupa wawancaran dan tes.

Instumen yang digunakan untuk penelitian berupa pedoman wawancara dan tes. Pedoman wawancara dibuat agar wawancara yang dilakukan bisa sistematis dan sesuai dengan target penelitian. Pedoman wawancara berbentuk poin inti pertanyaan. Berisi tentang penggalian penalaran adaptif

\footnotetext{
${ }^{11}$ Marjorie Henningsen dan Mary Kay Stein, "Mathematical tasks and student cognition: Classroom-based factors that support and inhibit high-level mathematical thinking and reasoning,"
}

siswa tentang konsep hitung bilangan bulat di kelas rendah. Pemilihan bentuk poin pertanyaan agar memudahkan peneliti untuk mengembangkan pertaanyaan. Karena tiap pertanyaan harus menunggu respon dari subjek penelitian. Respon dari subjek penelitian tiap subjek berbeda berhantung kemampuan komunikasi dari siswa.

Selain pedoman wawancara, instrumen penelitian berupa tes. Tes pada penelitian ini berjenis soal dengan model open ended. Jenis soal open ended digunakan agar siswaa bisa menceritakan kemampuan penalaran adaptif mereka. Soal open endded memungkinkan siswa menjawab dengan berbagai variasi yang sesuai dengan tingkat pemahaman mereka. Soal tes ini sebagai pengantar untuk menggali penalaran adaptif siswa. Soal ini membantu peneliti untuk melakukan kegiatan wawancara. Karena peneliti melakukan pertanyaan bersumber dari pengerjaan hitung siswa dari mengerjakan soal.

Pada saat melaakukan wawancara. Instrumen penelitian paling penting adalah peneliti sendiri. Karena peneliti adalah salah satu instrumen dalam penelitian ${ }^{12}$. Salah satu tugas dari peneliti saat wawancara adalah menggali data sebanyak mungkin. Data bisa ambil dengan melihat respon dan gerakan dari subjek penelitian. Karena respon tiap subjek berbeda bergantung dengan karakter individu masing-masing. Oleh karena itu peneliti harus responsif dan mudah berkomunikasi agar subjek tidak terintimidasi dan menjawab pertanyaan wawancara sejelas mungkin.

Journal for research in mathematics education, 1997, 524-549.

${ }^{12}$ Lexy J. Moleong, Metodologi Penelitian Kualitatif (Bandung: Remaja Rosda Karya, 1999). 
Penelitian ini menggunakan reduksi data. Sebelum proses reduksi, semua data dari proses pengumpulan data dikumpulkan terlebih dahulu. Kemudian dicek sampai semua data yang diperlukan sudah cukup dan bisa dianalisis. Proses reduksi data pada penelitian ini adalah proses data yang sudah ada dipilih. Pemilihan data ini agar data yang dibutuhkan sesuai dengan tujuan penelitian dan tidak menyimpang dari tujuan penelitian.

Reduksi data dilakukan dengan mengumpulka data dalam 3 kategori. Kategori penelitian ini berdasarkan tingkat kognitif siswa. Kognitif siswa pada penelitian ini adalah kognitif tinggi, sedang dan rendah. Reduksi data pada penelitian dengan mengumpukan data berdasarkan pengkategorian tersebut. Sehingga hasil reduksi data pada penelitian berupa penalaran adaptif siswa yang berkognitif tinggi, sedang dan rendah. Langkah yang dilakukan pada tahap ini memilah dan memilih data sesuai dengan katageri. Data yang sesuai dikumpulkan data yang tidak sesuai dihilangkan. Tetnatunya tujuan dari langkah reduksi agar analisa yang dilakukan pada tahap berikutnya bisa mudah.

Hasil reduksi data selanjutnya akan dikumpulkan sesuai kategori penalaran deduktif. Data yang sudah sesuai dengan kategori selanjutnya di narasikan secara deskriptif. Tujuan menarasikan deskriptif agar data yang diproleh bisa diamati bentuk penalaran adaptif siswa. Hasil penalaran akan di deskriptifkan dalam kategori kognitif. Selain itu narasi juga akan dibantu dengan beberapa gambar dari pekerjaan siswa. Tujuan gambar agar deskriptif data penalaran adaptif yang sudah dideskriptifkan bisa lebih jelas. Pada tahapan ini akan dikupas data yang akan di jelaskan dalam analisi hasil penelitian
Setelah data disajikan,maka dilakukan penarikan kesimpulan atau verifikasi. Untuk itu diusahakan mencari pola, model, tema, hubungan, persamaan, hal-hal yang sering muncul, hipotesis dan sebagainya. Jadi dari data tersebut berusaha diambil kesimpulan. Hasil kesimpulan juga akan dipadu dengan teori-teori yang sudah ada sebelumnya. Sehingga kekuataan analasis bisa lebih bagus. Verifikasi dapat dilakukan dengan keputusan, didasarkan pada reduksi data, dan penyajian data yang merupakan jawaban atas masalah yang diangkat dalam penelitian.

\section{Paparan Hasil Penelitian}

Peneliti melakukan penelitian pada tanggal 19 Juni 2018. Pada paparan data akan dipapaprkan hasil data pada masingmasing siswa berdasarkan kemampuan kognisi. Data diperoleh dengan cara wawancara dan pemberian soal tes. Soal tes digunakan utuk memancing kemapan siswa dalam mengkomunikasikan dan merepresentasikan pengetahuan yang diperoleh.

Pada siswa berkemampuan rendah, siswa merasa kesulitan mengkomunikasikan gambar dari bangun persegi panjang. Kesulitan ini karena siswa terkadang lupa dan bingung tetang bentuk bangun ketika dikaitkan dengan soal cerita. Sehingga perlubantuan dari guru untuk mengingatkan gambar persegi panjang dan menentukan letak panjang dan lebar pada gambar tersebut. Setelah selesai menggambar siswa juga masih ragu untuk menentukan posisi panjang dan lebar pada gamabar yang sudah dibuat. Keraguan ini karena kurang percaya diri kurangnya kemampuan 
berlaatih mengkaitkan bangun dengan soal dalam kehidupan sehari hari.

Siswa dengan kemampuan sedang juga lupa tentang menggambarkan bangun datar persegi panjang sama seperti siswaa dengan kemampuan rendah. Tetapi siswa dengan kemampuan sedang mampu menjelaskan letak panjang dan lebar pada gambar yang dibuat. Panjang dan lebar digambarkan dengan tepat pada kerjaan soalnya. Penjelasan cara mencari keliling dijelaskan dengan acuan gambar yang sudah dibuatnya.

Siswa dengan kemampuan kognitif tinggi dengan lancar menghubungkan soal dengan gambar persegi panjang yang dibuatnya. Siswa dengan kemampua tinggi mennjelaskan letak panjang dan lebar pada gambarnya. Panjang pada gambar diposisikan dengan sisi yang lebih panjang dibandingkan dengan sisi lebarnya. Kemampuan menghubungkan ide dengan gambar diperoleh dengan sering berlatih mengerjakan soal-soal yaang berkaitan dengan bangun persegi panjang.

Pada saat proses perhitungan, siswa dengan kemampuan rendah mengerhitung menggunakkan rumus keliling persegi panjang. Siswa kesulitan ketika menghitung keliling persegi panjang dengan konsep keliling $2^{*}(\mathrm{p}+\mathrm{l})$. Siswa kemampuan rendah mengerjakannya dengan menjumlahkan panjang masing-masing sisi. Alasan dari pengerjaanya karena kemampuan melakukan perkalian belum kuat. Sehingga konsep penjumlahan yang lebih bisa diterapkan.

Siswa dengan kemampuan sedang pada proses perhitungan menggunkan rumus yang dipelajari. Rumus keliling menggunakan rumus $2^{*}(\mathrm{p}+\mathrm{l})$. Tetapi saat ditanya hubungan perhitungan keliling dengan gambar yang dibuat, siswa beremampuan sedang belum tidak tahu. Siswa berkemampuan sedang menganggap berbeda antar rumus dengan gambar yang diperolehnya.Pada konsep perhitugan luas siswa dengan kemapuan sedang juga masih menghitung hanya sekedar rumus. Siswa dengan kemampuan sedang belum dapat mengkaitkan antara gambar dengan perhitungan yang dilakukan.

Siswa dengan kemampuan tinggi mengolah pemahaman tentang rumus yang diperoleh sesuai dengan gambar. Pada konsep menghitung keliling persegi panjang siswa dengan kemampuan tinggi menjelaskan asal dari rumus $2 *(p+l)$. Pemahan konsep tentang keliling persegi panjang bisa dijelaskan.Tetapi pada konsep perhitungan Luas persegi panjang, siswa dengan kemapuan tinggi kesulitan dalam mengkaitkan dengaan gambar dengan perhitunganya. Siswa dengan kemamouan tinggi belum dapat mengabstraksi konsep satuan luas dengan baik.

Siswa dengan kemampuan tinggi hanya menjelaskan perhitungan berdasarkan dengan rumus

Pada soal nomor 2, Siswa dengan kemampuan rendah kesulitan mengerjakan. Soal nomor 2 merupakan soal dengan jenis mengkaitkan materi dalam bentuk kehidupan sehari hari. Kesulitan yang dialami oleh siswa dengan kemampuan rendah yaitu saat mengkaitakan Luas dengan bangun persegi panjang. Kesulitan yang dialami 
saat membuat gambar tanah dari petani. Sehingga dalam melakukan perhitungan belum tahu rumus yang digunakan. Selain itu siswa dengan kemampuan rendah saat melakukan operasi hitung pembagian belum bisa. Sehingga mengkaitkan soal kehidupan sehari-hari dalam ide penyelesaian mengalaami kendala.

Siswa dengan kemampuan sedang juga mengalami hal yang sama tentang menyelesaikan masalah dalam kehidupan sehari-hari. Pada proses perhitungan, siswa dengan kemampuan sedang mampu melakukan perhitungan. Tetapi dalam proses nalar mengkaitkan soal berbentuk kehidupan sehari-hari siswa dengan kemampuan sedang mengalami kendala. Kendala ini dikarenakan belum terbiasanya siswa menjumpai permasalahan (soal).

Siswa kemampuan tinggi mampu menalar dengan baik soal yang berkaitan dengan kehidupan sehari-hari. Kemampuan menyelesaikan soal yang bekaitan dengan kehidupan sehari dilakukan dengan membuat gambar bangun. Gambar yang dibuat menurut siswa dengan kemampuan tinggi membaantunya dalam menalar sebelum proses perhitungan dilakukan. Kemampuan mengkaitkan soal dengan gambar ini diperoleh karena siswa sudah terbiasa mengkaitkan hal-hal dengan gambar.

Pada saat semua siswa berdiskusi menyelesaikan soal yang kurang dipahami, siswa dengan kemampuan rendah termasuk yang kurang aktif dalam membahas soal. Siswa dengan

\footnotetext{
${ }^{13}$ Interview dengan siswa berkemampuaan rendah.
}

kemampuan rendah kurang mampu berdiskusi dengan rekan sejawat untuk membahas strategi penyelesaian. Tetapi ketika berdiskusi dengan guru, siswa dengan kemampuan rendah sangat aktif dan sering bertanya. Menurut salah satu subjek siswa dengan kemampuan rendah (nama dirahasiakan) ${ }^{13}$, dia merasa malu ketika berdiskusi dengan temanya. Karena dia merasa banyak yang tidak tahu. Saat menulis pun terkadang siswa dengan kemapuan rendah cenderung ragu. Keraguan ini terlihat ketika dia baru menulis setelah memastikan ke rekan sejawat dan guru tentang yang rencana yang dia buat.

Siswa dengan kemampuan sedang termasuk siswa yang aktif dalam berdiskusi tetang penyelesaian masalah matematika. Siswa termasuk aktif bertanya kepada rekan sejawat tentang penyelesaian yang coba dia selesaikan, Tidak hanya dengan rekan sejawat, siswa dengan kemampuan sedang juga aktif bertanyaa kepada guru untuk berdiskusi tentang penyelesaian maasalah matematika yang diberikan oleh peneliti. Keaktifan siswa dengan kemampuan sedang dalam berdiskusi dikarenakan keingin tahuan dalam menyelesaikan masalah mereka. 14 Siswa dengan kemampuan sedang juga aktif mmbantu teman yang juga kurang paham, walaupun yang diajarkan kepada temanya kada juga dia tidak yakin hasilnya.

Siswa dengan kemampuan tinggi kurang begitu aktif berdiskusi dengan guru dan rekan sejawat. Siswa dengan kemampuan tinggi cenderung pasif

\footnotetext{
${ }^{14}$ Interview dengan siswa dengan kemampuan sedang.
} 
dengan guru karena merasa sudah mampu memahami materi yang sudah dijelaskan oleh guru. Tetapi andaikan ada materi yang belum dipahami, siswa dengan kemampuan tinggi baru aktif berdiskusi. Siswa dengan kemampuan tinggi juga jarang aktif berdiskusi dengan rekan sejawat. Siswa dengan kemampuan tinggi menunggu jika ada rekan yang bertanya baru dia menjelaskan. Tidak aktif menanyakan, ketika ada teman yang kurang paham.

Siswa dengan kemampuan rendah kesulitan mengkaikan pemaahaman dengan konsep pada persamaan matematika. Seperti saat memasukkan nilai panjang dan lebar pada soal cerita. Rumus sudah paham, tetapi memasukkan nilainya masih ada keraguan. Hal itu karena rasa percaya diri kurang dan tidak yakin tentang yang dilakukan.

Siswa dengan kemampuan sedang dan tinggi melalui bahasa tulisan mampu mengkaitkan antara pemahaman dengan simbol. Hal itu terlihat dari cara pegerjaannya, siswa dengan kemampuan sedang dan tinggi dapat memaasukkan nilai panjang, lebar, Luas dan Keliling kedalam persamaan matematika. Kemampuan mengkaitkan ini diperoleh karena sudah biasa, dan juga siswa sudah mampu mengkonstruksi pengetahuannya dengan baik.Pembiasaan penyelesaianya ini diperoleh saat mengerjaakan latihan oleh guru berupa tugas dikelas maupun pekerjaan rumah. Terkadang pembiasaaan ini dilakukan dirumah dengan belajar mandiri ataupu dengan mengikuti bimbingan belajar.

Selama pengerjaaan soal, siswa dengan kemampuan rendah melakukaan pertanyaan terkait dengan cara melakukan perhitungan. Pertanyaan ini dilakukan karena pada taraf perhitungan siswa belum begitu memahami. Terutama untuk operasi hitung perkaliaan dan pembagian. Pertanyaan yang ditanyakan oleh siswa dengan kemampuan rendah jarang yang mengenai konsep tentang materi. Konsep pengembangan materi masih belum tertanyakan karena pemahaman belum terkonstruksi.

Siswa dengan kemampuaan sedang dan tinggi bertanya tentang proses pengerjaan yang lupa. Selain itu juga menanyakan tentang konsep materi persegi panjang yang dikaitkan dengan permasalahn yang disajikan. Tetapi konsep yang ditanyakan masih terkait dengan materi. Siswa jarang bertanya tentang pengembaangaan materi, ataupun konsep kritis tentang materi.

Pada konsep menarik kesimpulan dalam tulisan dan lisan yang diutaarakan, siswa dengan kemampuan sedang belum mampu menyampaikan dengan jelas. Pada tulis hasil yang didapat hanya sebatas nilai belum ada keterangan yang menampilkan luas atau keliling (yang ditanyakan soal). Ketika diwawancarai siswa tidak begitu lancar menyampaikan hasil yang dia hitung. Hanya menunjukkan nilai yang diperoleh dari perhitungannya. Penjelasan hasil yang dikaitkan dengan konsep materi masih belum jelas.

Siswa dengan kemampuan sedang dan tinggi dalam bahasa tulis menjelaskan perhitungan secara sistematis. Tetapi dalam bahasa tulis belum terlihat konjektur dari perhitungannya. Hanya ketika ditanya secara lisan siswa dengan kemampuan sedang bisa menjelaskan 
hasil perhitungan. Siswa dengan jelas menjelaskan maksud perhitungan dengan permasalahan (berkaitan dengan persegi panjang) yang diberikan. Kemampuan penyimpulan dalam bahasa tulis belum mampu dilakukan oleh siswa dengan kemampuan sedang dan tinggi karena siswa belum terlatih dalam menulis. Siswa terlatih hanya melakukan perhitungan.

\section{Pembahasan}

Pada proses komunikasi ada beberapa aspek yang perlu dipahami. Aspek komunikasi akan dikategorikan menjadi 4 aspek sebagai berikut

1. Mengajukan konjektur (dugaan yang bersifat residensi)

Siswa berdasarkan hasil paparan data yang ada pembahasan sebelumnya mengalami beberapa kendala dalam menghubungkan benda datar dari soal menjadi sebuah gambar dalam bentuk real. Kesulitan ini terjadi karena dalam hal abstraksi siswa belum mampu dengan baik dikonstruksi. Kegagalan ini dikarenakan guru kurang memberikan contoh-contoh dan terapan sesuai dengan realita yang ada pada kehidupan sehari hari. Hal ini didukung oleh Cai ${ }^{15}$, salah satu peran guru dalam mengajar komunikasi matematika adalah dengan memberikan variasi soal yang baik untuk siswa. Sehingga dengan variasi soal yang berkaitan dengan kehidupan sehari hari siswa bisa terbiasa dan mampu mengkaitkan soal dengan realita. Hal itu didukung dengan kemampuan siswa dengan kemampuan tinggi yang mampu mengkaitkan soal dengan gambar. Siswa dengan kemampuan tinggi mampu mengkaitkan karena siswa sudah sering berlatih. Siswa dangan kemampuan tinggi tidak hanya berlatih disekolah tetapi juga berlatih dirumah. Tugas terstruktus bisa sebagai alternatif usaha agar siswaa mampu mengkaitkan soal dengan gambar.

2. Memberikan alasan atau bukti terhadap

kebenaran suatu pernyataan

Berdasarkan hasil paparan data, siswa mengalami kendala dalam menyampaikan ide baik dengan llisan dan tulisan. Kesulitan utamanya dalam bentuk tulisan siswa belum mampu mengkaitkan hasil gambar bangun datar yang digambar dengan nilai panjang yang lebar yang sudah diketahui pada soal. Ketidak mampuan menjelaskan gambar yang sudah digambar dengan besarnya nilai yang sudah diperoleh karena siswa masih belum bisa mengabstraksi. Selain itu juga didukung dengan siswa hanya biasa melakukan perhitungan. Perhitungan memang perlu dipahami oleh siswa, tetapi siswa cenderung kurang mampu berkomunikasi ketika fokus perhitungan tidak diertai dengan konsep realita. Akibatnya siswa menjelaska konsep perhitungan yang benar dengan menggunakan bantuan benda nyata maupun gambar.

Penjelasan ide bisa dilakukan dengan baik oleh oleh siswa dengan kemampuan tinggi. Kemampuan menjelaskan ide dengan baik diperoleh dengan kuatnya konsep yang sudah dipunyai oleh siswa dengan kemampuan. Konsep matematika yang dimaaksud adalah prasyarat materi sebelum materi bangun datar. Konsep itu

\footnotetext{
${ }^{15}$ Cai, Jakabcsin, dan Lane, “Assessing students' mathematical communication."
} 
berupa kemampuan melakukan operasi hitung bilangan bulat. Kemampuan melakukan operasi hitung bilangan bulat membantu ketika gambaran gambar dipadukan dengan hasil perhitungan yang dikerjakan oleh siswa dengan kemampuan tinggi. Berbeda dengan siswa dengan kemampuan sedang rendah yang cenderung kesulitan menjelaskan ide baik secara lisan maupun tulis. Siswa dengan kemampuan sedang dan rendah masih konsen ke perhitungan sehingga belum mampu ketika dipancing untuk menyampaikan ide kedalam bentuk matematika.

3. Menarik kesimpulan suatu pernyataan.

Siswa merasa kesulitan ketika soal dikaitkan dengan kehidupan sehari-hari. Hal itu berlaku untuk siswa dengan kemampuan rendah, sedang dan tinggi. Siswa kesulitan dalam menyatakan peristiwa sehari-hari pada paparan data terlihat karena siswa hanya terlalu fokus pada materi perhitungan. Sehingga ketika sudah mampu mencari keliling maupun luas dari bangun datar pesegi panjang, siswa cenderung tidak mampu mengkonstruksi ide mereka. Selain itu juga sama seperti faktor sebelumnya kurangnya kemampuan berlatih siswa dalam menyelesaikan soal yang berkaitan dengan kehidupan sehari-hari merupakan penyebab siswa belum mampu mengkonstruksi pemahamnya.

4. Memeriksa kesahihan suatu alasan

Kemampuan berdiskusi tentang matematika merupakan kemampuan dalam mengkomunikasikaan pikiran. Siswa dengan kemampuan sedang dan tinggi cenderung kurang mampu dalam berdiskusi. Siswa dengan kemampuan sedang kurang mampu berdiskusi matematika kurangnya pemahaman dalam materi tersebut. Sedangkan siswa dengan kemampuan tinggi juga kurang mampu berdiskusi karena materi yang didiskusikan sudah dipaahami sehingga ketika diskusi matematika cenderung non aktif. Siswa dengan kemampuan tinggi non aktif karena merasa diskusi matematikaa yang dilakukan kurang menarik untuk dilakukan.

Siswa dengan kemampuan sedang aktif ketika berdiskusi membahas tentang bangun datar persegi panjang. Hal itu karena kemampuan yang dimiliki siswa dengan kemampuan sedang yang cukup untuk membahas materi bangun datar. Selain itu juga siswa dengan kemampuan merasa masih belum begitu paham. Sehingga ketika diskusi membahas konsep bangun datar persegi panjang siswa dengan kemampuan sedang aktif menanyakan hal-hal yang belum dipahami.

\section{E. Kesimpulan dan Saran}

Berdasarkan hasil analisis data diperoleh ada beberapa faktor yang mempengaruhi komunikasi matematis siswa pada materi bangun datar persegi panjang yaitu latihan dalam menyelesaikan pemecahan masalah yang berkaitan dengan kehidupan sehari, pemahaman materi operasi hitung bilangan bulat, kepercayaan diri siswa, dan Kemampuan menulis literasi matematis. Faktor-faktor yang mempengaruhi itu perlu dijaga agar kemampuan komunikasi siswa tentang materi bangun datar persegi panjang bisa dilakukan oleh siswa. 
Berdasarkaan hasil analisis data, diperoleh beberapa faktor yang mempengaruhi kemampuan representasi siswa dalam memahami materi bangun datar persegi panjang yaitu Pemaham konsep gambar, latihan Soal berbasis pemecahan masalah, dan Berlatih menulis secara sistematis. Representasi yang dimiliki siswa merupakan salah satu aspek yang bisa digunakan untuk melihat kemampuan siswa. Sehingga menjaga faktor-faktor yang mempengaruhi representasi siswa merupakan salah satu usaha agaar pemahaman siswa bisa terkonstruksi dengan baik.

Perlu diadakan peneilitian lebih lanjut terkait komunikasi dan representasi siswa pada materi yang lain selain bangun datar. Karena konsep geometri pada sekolah tingkat Madrasah Diniyah sangat banyak. Selain itu pengembangan penelitian yang bisa dikaitkan dengan representasi, dan komunikasi matematis. Sehingga variabel yang berkaitan dengan komunikasi dan representasi bisa diketahui. Perlu juga dilakukan penelitian lanjut terkait dengan desain pembelajaran yang bisa meningkatkan komunikasi dan representasi siswa.

\section{F. Daftar Referensi}

Ani, Minarni. "Peran Penalaran Matematik Untuk Meningkatkan Kemampuan pemecahan Masalah Matematik Siswa." In Prosiding Seminar Nasional Matematika dan Pendidikan Matematika (2010):" Peningkatan Kontribusi Penelitian dan Pembelajaran Matematika dalam Upaya Pembentukan Karakter Bangsa". Jurusan Pendidikan Matematika FMIPA UNY, 2010.

Cai, Jinfa, Mary S. Jakabcsin, dan Suzanne Lane. 'Assessing students' mathematical communication." School Science and Mathematics 96, no. 5 (1996): 238-246.

Council, National Research, dan

Mathematics Learning Study Committee. Adding it up: Helping children learn mathematics. National Academies Press, 2001.

Fatimah, Fatia. "Kemampuan Komunikasi Matematis dalam Pembelajaran Statistika Elementer melalui Problem Based-Learning." Jurnal Cakrawala Pendidikan 5, no. 2 (2013). http://journal.uny.ac.id/index.php/cp/ article/view/1562.

Fortune, Tara. "Scaffolding Techniques in CBI Classrooms." Online at the, 2004.

Hadi, Sofwan. "Scaffolding dalam Menyelesaikan Permasalahan KPK dan FPB." Ibriez: Jurnal Kependidikan Dasar Islam Berbasis Sains 1, no. 1 (2016): 141-148.

Henningsen, Marjorie, dan Mary Kay Stein. "Mathematical tasks and student cognition: Classroom-based factors that support and inhibit high-level mathematical thinking and reasoning." Journal for research in mathematics education, 1997, 524549.

Hudojo, Herman. "Representasi belajar berbasis masalah." Jurnal Matematika dan Pembelajarannya. ISSN, 2002, 085-7792.

Hwang, Wu-Yuin, Nian-Shing Chen, JianJie Dung, Yi-Lun Yang, dan others. 
"Multiple representation skills and creativity effects on mathematical problem solving using a multimedia whiteboard system." Educational Technology \& Society 10, no. 2 (2007): 191-212.

Knuth, R. A., dan B. F. Jones. "What does research say about mathematics." Retrieved September 10 (1991): 2006.

Lestari, Karunia Eka, dan Mokhammad Ridwan Yudhanegara. Penelitian Pendidikan Matematika. Bandung: Refika Aditama, n.d.

Luitel, B. C. "Multiple representations of mathematical learning." Tersedia: http://www. matedu. cinvestav. mx/Adalira. pdf, 2001.

Mathematics, National Council of Teachers of. Principles and standards for school mathematics. Vol. 1. National Council of Teachers of, 2000.

Miles, Matthew B., dan A. Michael Huberman. Analisis data kualitatif. Diterjemahkan oleh Tjetjep Rohendi Rohidi. Jakarta: Universitas Indonesia, 1992.

Mustaqim, Mustaqim. "Scaffolding process Based on Diagnosis Students Difficulties in Solving Linear Program by Using Mapping Mathematic." Jurnal Pendidikan Sains (JPS) 1, no. 1 (2014): 72-78.

Ormrod, Jeanne Ellis.

PsikologiPpendidikan. 2 ed. Jakarta: Erlangga, 2008.

Sabirin, Muhamad. "Representasi dalam Pembelajaran Matematika." Jurnal Pendidikan Matematika 1, no. 2 (19 Agustus 2014): 33-44. https://doi.org/10.18592/jpm.v1i2.49
Sutawidjaja, Akbar, dan Jarnawi Afgani Dahlan. Pembelajaran matematika. Jakarta: Universitas Terbuka, 2014. Vygotsky, Lev Semenovich. Mind in society: The development of higher psychological processes. Harvard university press, 1980.

Wood, Derek. Kiat Mengatasi Gangguan Belajar. Jakarta: Kata Hati, 2007. 